\title{
A geochemical study of marine sediments from the Mac. Robertson shelf, East Antarctica: initial results and palaeoenvironmental implications
}

\author{
P. N. Sedwick, ${ }^{1}$ P.T. Harris, ${ }^{1,2}$ L. G. Robertson, ${ }^{1}$ G. M. McMurtry, ${ }^{3}$ M. D. Cremer, ${ }^{3}$ P. Robinson $^{4}$ \\ ${ }^{1}$ Antartic CRC, Box 252-80, Hobart, Tasmania 7001, Australia \\ ${ }^{2}$ Antarctic CRC and Australian Geological Survey Organisation, Box 252-80, Hobart, Tasmania 7001, Australia \\ ${ }^{3}$ Department of Oceanography, University of Hawaii, Honolulu, Hawaii 96822, U.S.A. \\ ${ }^{4}$ Department of Geology, University of Tasmania, Box 252-79, Hobart, Tasmania 7001, Australia
}

\begin{abstract}
Sediments from the Antarctic continental margin may provide detailed palaeoenvironmental records for Antarctic shelf waters during the late Quaternary. Here we present results from a palaeoenvironmental study of two sediment cores recovered from the continental shelf off Mac. Robertson Land, East Antarctica. These gravity cores were collected approximately $90 \mathrm{~km}$ apart from locations on the inner and outer shelf. Both cores are apparently undisturbed sequences of diatom ooze mixed with fine, quartz-rich sand. Core stratigraphies have been established from radiocarbon analyses of bulk organic carbon. Down-core geochemical determinations include the lithogenic components $\mathrm{Al}$ and $\mathrm{Fe}$, biogenic components opal and organic carbon, and palaeo-redox proxies Mn, Mo and U. We use the geochemical data to infer past variations in the deposition of biogenic and lithogenic materials, and the radiocarbon dates to estimate average sediment accumulation rates. The Holocene record of the outer-shelf core suggests three episodes of enhanced diatom export production at about 1.8, 3.8 and $5.5 \mathrm{ka} \mathrm{BP}$, as well as less pronounced bloom episodes which occurred over a shorter period. Average sediment accumulation rates at this location range from $13.7 \mathrm{~cm} \mathrm{ka}^{-1}$ in the late Pleistocene early Holocene to $82 \mathrm{~cm} \mathrm{ka}^{-1}$ in the late Holocene, and suggest that the inferred episodes of enhanced biogenic production lasted 100-1000 years. In contrast, data for the inner-shelf core suggest that there has been a roughly constant proportion of biogenic and lithogenic material accumulating during the middle to late Holocene, with a greater proportion of biogenic material relative to the outer shelf. Notably, there is an approximately 7 -fold increase in average sediment accumulation rate (from 24.5 to $179 \mathrm{~cm} \mathrm{ka}^{-1}$ ) at this innershelf location between the middle and late Holocene, with roughly comparable increases in the mass accumulation rates of both biogenic and lithogenic material. This may represent changes in sediment transport processes, or reflect real increases in pelagic sedimentation in this region during the Holocene. Our results suggest quite different sedimentation regimes in these two shelf locations during the middle to late Holocene.
\end{abstract}

\section{INTRODUGTION}

Much of our understanding of global change is derived from studies of marine sediments, which have provided regionalto basin-scale records of environmental conditions such as ocean circulation and biological production. The Antarctic continental shelves are the most biologically productive regions of the Southern Ocean (Comiso and others, 1993), and are important areas of deep-water formation (Deacon, 1984), yet palaeoenvironmental information for these waters is scant. This largely reflects the nature of marine sediments on the Antarctic continental margin: typically a complex mixture of poorly sorted terrigenous and biogenic material, often reworked by the action of ice and currents (Anderson and Molnia, 1989). However, some bathymetric depressions such as relict glacial troughs and fjords may act as natural sediment traps, allowing the accumulation of relatively undisturbed sequences of marine sediments derived from overlying waters. In some cases, these deposits may provide detailed records of environmental conditions for these regions during the late Quaternary (see, e.g., Domack and others, 1993; Leventer and others, 1996). Because environmental conditions such as algal production and sea-ice cover are highly variable around the Antarctic continental margin (Comiso and others, 1993), numerous such sedimentary records are required to establish palaeoenvironmental records on a regional scale. The study described here aims to extract palaeoenvironmental information from sediments on the continental shelf off Mac. Robertson Land, East Antarctica (Mac. Robertson Shelf). This region sustains some of the highest phytoplankton biomass of the Antarctic continental margin (Comiso and others, 1993), and may be an area of significant bottom-water formation (Nunes Vaz and Lennon, 1996). We are using geochemical techniques to examine the accumulation of biogenic and lithogenic material in a series of sediment cores recovered from the Mac. Robertson Shelf. Here we present geochemical data for two of these cores for which radiocarbon chronologies have been established, and discuss the palaeoenvironmental implications of these results. 


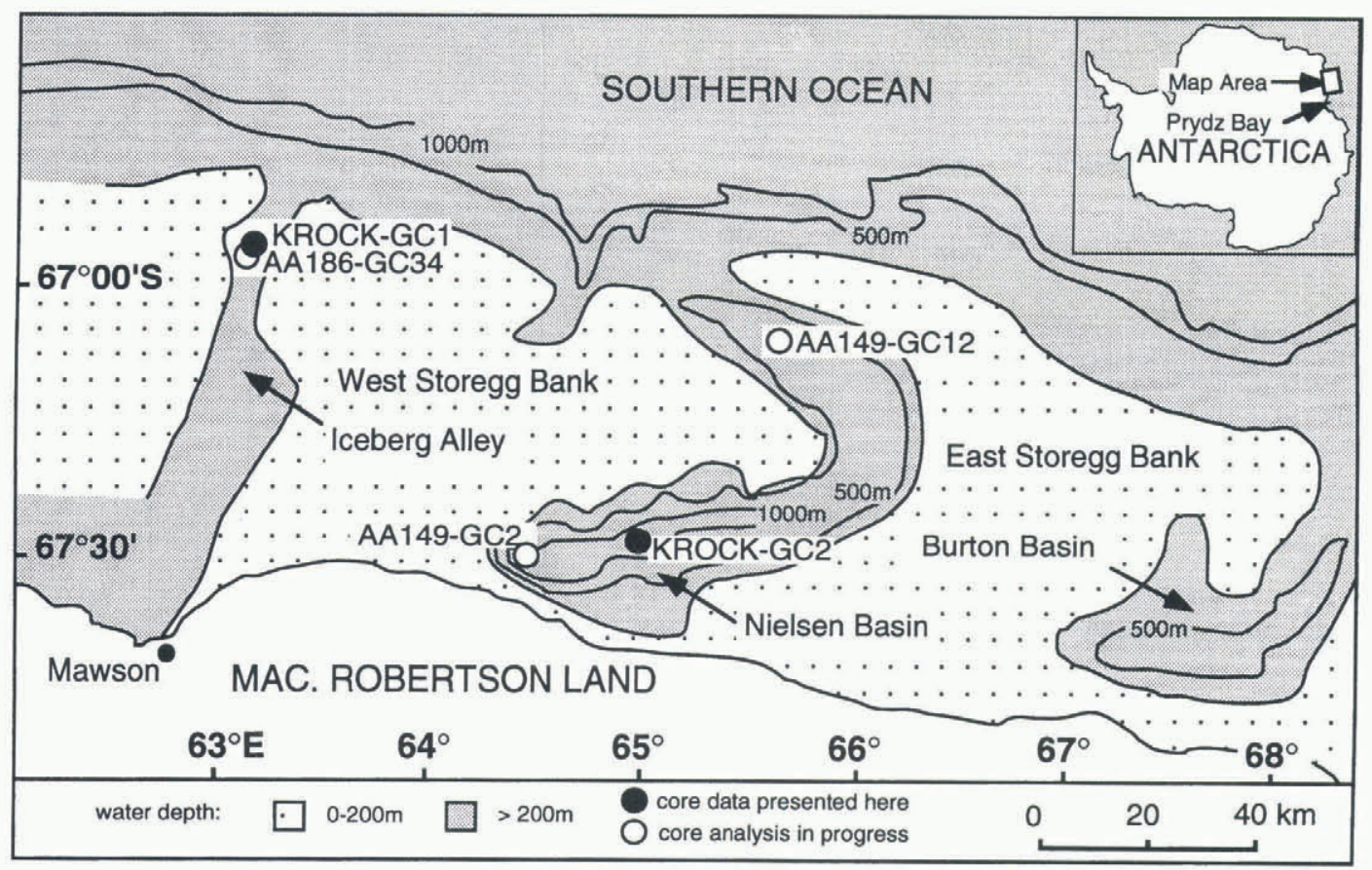

Fig. 1. Map of the Mac. Robertson shelf, showing locations of sediment cores under study.

\section{METHODS}

\subsection{Sample materials}

Sediment cores collected from the Mac. Robertson Shelf with RSV Aurora Australis in 1993, 1995 and 1997 are used in the present study (Fig. 1). These $8 \mathrm{~cm}$ diameter gravity cores were collected from two deep areas of the shelf, the Nielsen Basin (>1000 m water depth) and Iceberg Alley $(<500 \mathrm{~m}$ water depth), which are interpreted as relict glacial troughs (Harris and O'Brien, 1996). Results are presented here for two cores for which we have down-core radiocarbon dates and geochemical data, cores KROCK-GCl (hereafter GCl) and KROCK-GC2 (hereafter GC2). GCl was recovered from Iceberg Alley on the outer shelf, in $478 \mathrm{~m}$ of water, and GC2 was recovered from the Nielsen Basin on the inner shelf, in $1091 \mathrm{~m}$ of water. These sites are separated by a distance of roughly $90 \mathrm{~km}$. Both cores recovered apparently continuous sequences of diatom ooze with minor amounts of fine quartz sand and other fine lithogenic material. GCl has a total length of $363 \mathrm{~cm}$ of olive-green ooze, with numerous $\sim 1-10 \mathrm{~cm}$ thick bands of fluffy lighter-coloured material, and $\sim 5 \mathrm{~cm}$ of darker-coloured ooze at the base of the core. Core GC2 contains $293 \mathrm{~cm}$ of featureless olive-green ooze, except for $\sim 10 \mathrm{~cm}$ of darker olive-grey sandy material at the base of the core. The cores were split immediately after collection, wrapped in polyethylene, and stored refrigerated to minimise water loss. The cores were subsampled during 1994-95 in $10 \mathrm{~cm}$ intervals for geochemical analysis. In addition, $1 \mathrm{~cm}$ subsamples were taken from the upper $10 \mathrm{~cm}$ of each core for determination of excess ${ }^{210} \mathrm{~Pb} ; 1-2 \mathrm{~cm}$ subsamples were taken at selected depths for radiocarbon dating; and $1 \mathrm{~cm}^{3}$ subsamples were taken at $10 \mathrm{~cm}$ intervals for determination of dry bulk density. The uppermost section of GCl shrank in length from $100 \mathrm{~cm}$ to approximately $90 \mathrm{~cm}$ prior to subsampling, presumably due to water loss. In the presentation of data for this core, average sample depths between 0 and $90 \mathrm{~cm}$ were multiplied by a factor of 100/90 in an effort to correct for shrinkage.

\subsection{Core stratigraphy}

The cores are essentially devoid of carbonate microfossils, precluding use of $\delta^{18} \mathrm{O}$ stratigraphy and radiocarbon dating of calcium carbonate. Measurements of uranium-series radionuclides $\left({ }^{226} \mathrm{Ra},{ }^{230} \mathrm{Th},{ }^{231} \mathrm{~Pa}\right)$ may allow estimates of accumulation rates, although dating techniques using these radioisotopes generally require uniform sedimentation rates, which may not (and probably do not) apply to these cores. The principal chronostratigraphic tool we have employed in this study is ${ }^{14} \mathrm{C}$-dating of bulk organic carbon. Radiocarbon dates for subsamples of these sediment cores, which contain around $1-2 \%$ organic carbon, were determined by accelerator mass spectrometry at the Australian Nuclear Science and Technology Organisation and at the New Zealand Institute of Geological and Nuclear Sciences. Radiocarbon dates are reported here as conventional radiocarbon years before present (BP), as defined by Stuiver and Polach (1977). In addition, unsupported ${ }^{210} \mathrm{~Pb}$ was determined in the core-top subsamples by gamma spectrometry at the University of Hawaii, in an effort to evaluate recent accumulation rates, bioturbation and core-top losses.

\subsection{Geochemical measurements}

The geochemical measurements performed on the core subsamples include: bulk major and minor elements, determined in crushed, $60^{\circ} \mathrm{C}$-dried (and, for major elements, deionised-water washed) portions of the $10 \mathrm{~cm}$ subsamples by X-ray fluorescence spectroscopy following a modification of the method of Shimmield (1984); biogenic silica (opal), determined in freeze-dried portions of the $10 \mathrm{~cm}$ subsamples by the method of Mortlock and Froelich (1989); and total organic carbon, determined in crushed, $60^{\circ} \mathrm{C}$-dried, deionised-water washed portions of the $10 \mathrm{~cm}$ subsamples by the Isotope and Organic Geochemistry Laboratory of the Australian Geological Survey Organisation. The downcore geochemical data presented here are:

(1) total $\mathrm{Al}$ and $\mathrm{Fe}$, which provide an indication of terrige- 
nous inputs if it is assumed that most of these elements are associated with terrigenous material (Calvert and Pedersen, 1993; Kumar and others, 1995);

(2) total $\mathrm{Mn}$, which, when normalised to $\mathrm{Al}$ and compared with lithogenic abundance, provides information regarding down-core redox conditions (Calvert and Pedersen, 1993; Yang and others, 1995);

(3) total $\mathrm{U}$ and Mo, which, when normalised to $\mathrm{Al}$ and compared with lithogenic abundances, provide sensitive proxies of palaeo-redox conditions during sediment deposition (Calvert and Pedersen, 1993; Crusius and others, 1996);

(4) opal (assumed composition $\mathrm{SiO}_{2} \cdot 0.4 \mathrm{H}_{2} \mathrm{O}$ ), which has been used to infer palaeoproductivity in the Southern Ocean where the degree of post-depositional preservation is high or relatively constant (Charles and others, 1991; Mortlock and others, 1991);

(5) total organic carbon (TOC), which has been used to infer palaeoproductivity in sediments from the Antarctic continental shelf (Leventer and others, 1996); and

(6) excess (or biogenic) Ba, which in non-reducing sediments may provide a proxy record of productivity in overlying waters (Dymond and others, 1992). Biogenic $\mathrm{Ba}$ is calculated from total $\mathrm{Ba}$ minus lithogenic $\mathrm{Ba}$, where lithogenic $\mathrm{Ba}$ is estimated as $0.0075 \mathrm{Al}(0.0075$ is the average crustal weight ratio of $\mathrm{Ba} / \mathrm{Al}$; Dymond and others, 1992).

The down-core geochemical data have been plotted against the average depth of each $10 \mathrm{~cm}$ subsample in the core.

\section{RESULTS AND DISGUSSION}

\subsection{Core preservation and chronostratigraphy}

The down-core radiocarbon dates increase in a regular fashion for both cores (Fig. 2), suggesting that the cores contain continuous records of sedimentation extending back to the late Pleistocene for GCl and mid-Holocene for GC2. The upper $10 \mathrm{~cm}$ of both cores contained no unsupported ${ }^{210} \mathrm{~Pb}$, suggesting that at least $\sim 200$ years of the uppermost sediments have been lost during collection of the cores. This is not unexpected, given the relatively small bore of the gravity corer used and the high water content of the fine diatom ooze. Organic matter at the sediment-water interface typically has a non-zero radiocarbon age, as a result of (1) the non-zero radiocarbon age of organic matter in the photic zone (assumed to be the principal source of organic carbon in these sediments), known as the reservoir effect, (2) bioturbation, and (3) dilution of fresh sediments by older, resuspended material. To correct our raw radiocarbon ages (Fig. 2) for these processes, we have subtracted 1730 radiocarbon years $\mathrm{BP}$, which is the measured age of a surface-sediment grab sample (AA186-GB9) recovered near the location of GC2 (this supplants an earlier correction of 1094 radiocarbon years BP used in Harris and others, in press). The corrected radiocarbon ages are presented in Figure 3 , which we compare with the conventional radiocarbon time-scale. Using sedimentation rates of $82 \mathrm{~cm} \mathrm{ka}^{-1}$ for the upper part of $\mathrm{GCl}$, and $179 \mathrm{~cm} \mathrm{ka}^{-1}$ for the upper part of GC2 (see section 3.3), the corrected core-top ages of $0.90 \mathrm{ka} \mathrm{BP}$ for $\mathrm{GCl}$ and $0.30 \mathrm{ka} \mathrm{BP}$ for GC2 then suggest

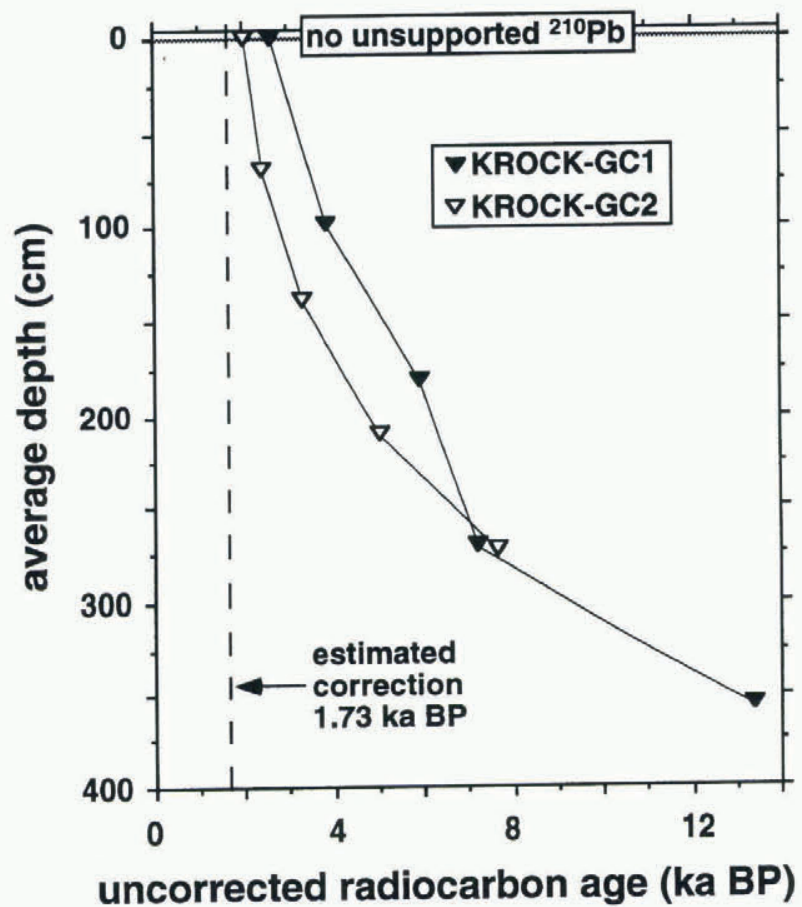

Fig. 2. Down-core uncorrected radiocarbon ages for cores KROCK-GC1 and KROCK-GC2.

core-top losses of 74 and $54 \mathrm{~cm}$, respectively. The radiocarbon data therefore suggest that GCl represents a continuous sedimentary record from around 11700 to 900 radiocarbon years BP, and GC2 represents a continuous sedimentary record from around 5940 to 300 radiocarbon years BP.

\subsection{Down-core geochemical records}

Down-core geochemical data (Al, Fe, Mn, Mo/Al, U/Al, opal, TOC and excess $\mathrm{Ba}$ ) are presented for the two cores in Figure 3. Both cores are roughly similar in terms of bulk composition, containing around $30-50 \%$ opal and $0.5-2 \%$ TOC on a dry-weight basis. Down-core Mn concentrations are low and uniform in both cores, with $\mathrm{Mn} / \mathrm{Al}$ close to the average shale ratio of 0.08 (Wedepohl, 1971), whereas Mo and $\mathrm{U}$ are enriched relative to average shale ratios of $\mathrm{Mo} /$ $\mathrm{Al} \sim 0.3 \times 10^{-4}$ and $\mathrm{U} / \mathrm{Al} \sim 0.4 \times 10^{-4}$ (Wedepohl, 1971). Together, these trace-element data suggest that sediments accumulated at these sites under anoxic conditions, perhaps up to the sediment-water interface (Calvert and Pedersen, 1993; Crusius and others, 1996). Such anoxic conditions promote diagenetic dissolution of biogenic barite and remobilisation of $\mathrm{Ba}$ within the sediment column (Dymond and others, 1992), casting doubt on the utility of excess Ba as a palaeoproductivity proxy in these cores.

There are obvious contrasts in the down-core geochemical records of $\mathrm{GCl}$ and GC2, suggesting significant differences in the composition, transport or preservation of sediments between the two sites. For GCl, there are four pronounced down-core minima in $\mathrm{Al}$ and $\mathrm{Fe}$ (shaded bands in Fig. 3a) which are roughly coincident with local maxima in $\mathrm{U} / \mathrm{Al}$ and $\mathrm{Mo} / \mathrm{Al}$ (Fig. 3b), and small local maxima in opal (Fig. 3c) and TOC (Fig. 3d). These down-core compositional changes suggest episodes of decreased terrigenous inputs ( $\mathrm{Al}$ and $\mathrm{Fe}$ minima) and more reducing conditions within the sediments (Mo and U maxima), associated with increased deposition of siliceous biogenic material (opal and TOC maxima). These compositional "episodes" 


\section{KROCK-GC1 outer shelf}

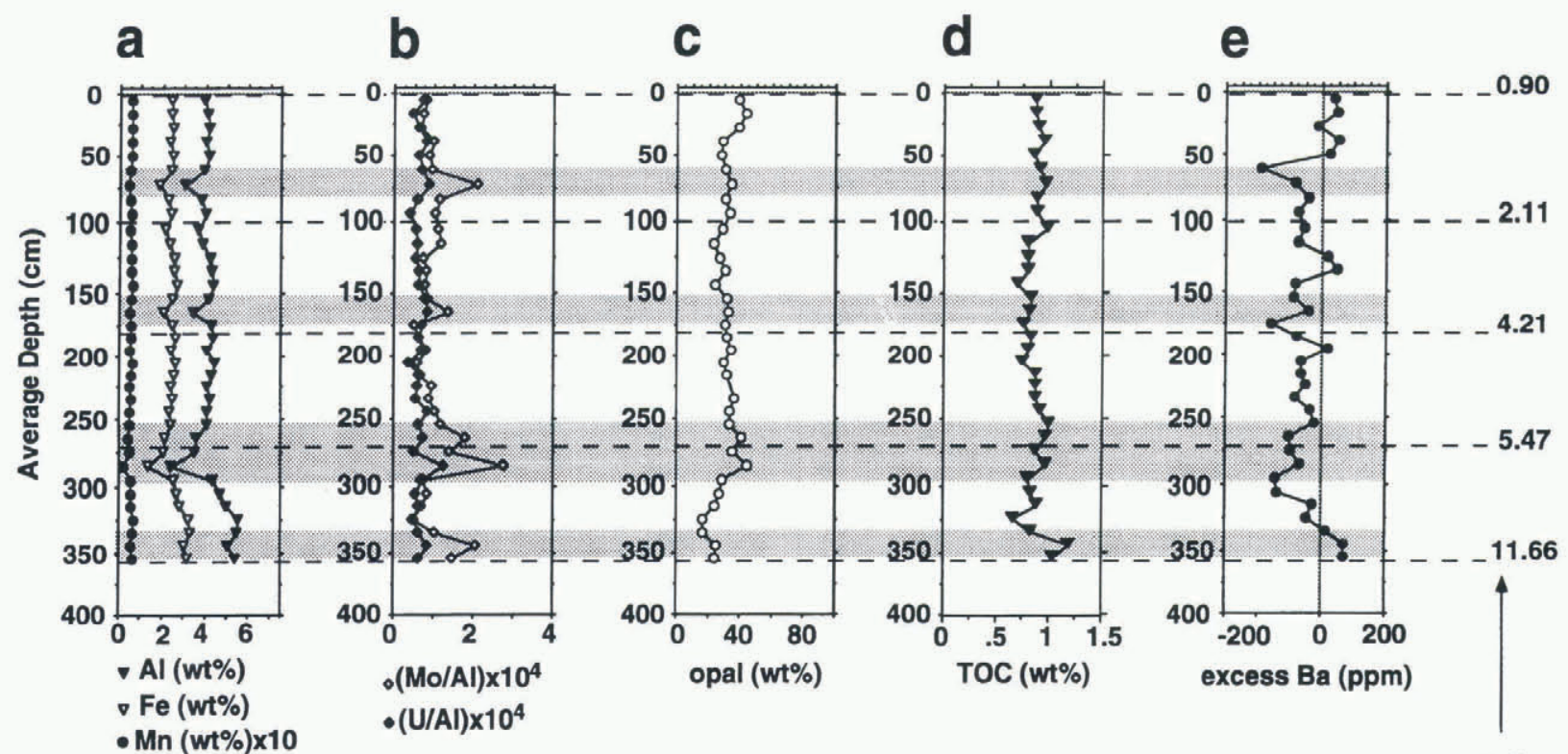

- Mn (wt\%)x10

\section{KROCK-GC2 inner shelf}

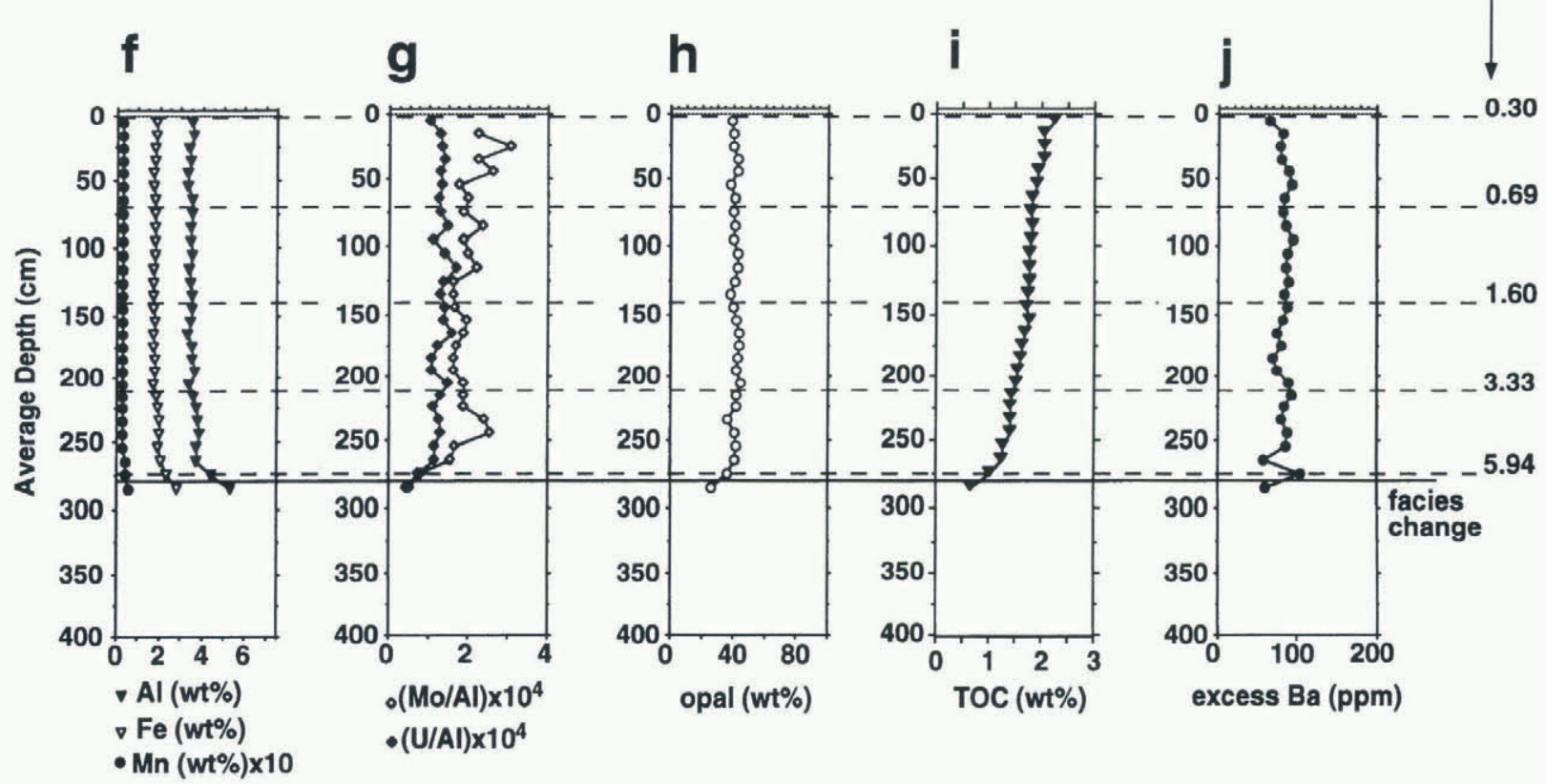

Fig. 3. Down-core geochemical data and corrected radiocarbon ages for cores KROCK-GC1 $(a-e)$ and KROCK-GC2 (f-j). Shaded bands indicate inferred bloom episodes.

coincide with layers of highest water content, and roughly correspond to some (but not all) of the thicker light-coloured bands in the core, except for the episode near the base of the core which occurs within relatively consolidated darkcoloured material.

We tentatively ascribe the down-core banding in $\mathrm{GCl}$ to changes in species composition of diatoms within the biogenic sediment fraction, rather than, for example, banding due to dilute sediment gravity flows. A micropalaeontological investigation of this core has shown that the diatom Fragilariopsis curta dominates the darker bands, whereas the lighter bands contain an increased abundance of the diatoms Corethron criophilum and Fragilariopsis cylindrus, and the darker material at the base of the core is characterised by an almost monospecific assemblage of Chaetoceros resting spores (personal communication from F. Taylor, 1997). Both C. criophilum and F. cylindrus are lightly silicified and thought to be poorly preserved in sediments (Jordan and others, 1991; Leventer and others, 1996; personal communication from F. Taylor, 1997), so the light-coloured bands in GCl may result from massive blooms of these species in overlying waters. A simple interpretation of the down-core geochemical record for $\mathrm{GCl}$ is that the minima in terrigenous components record episodes of enhanced export production by Corethron criophilum and/or Fragilariopsis cylindrus (or Chaetoceros at the base of the core), creating more reducing condi- 
tions within the sediments. Calculated sediment accumulation rates for this core (see section 3.3) suggest that these compositional episodes, which we interpret as periods of enhanced export production, may have occurred over periods of 100-1000 years, although these layers could have accumulated more rapidly over shorter periods. The numerous thin $(\sim 1-5 \mathrm{~cm})$ light-coloured bands within the core may thus record shorter periods ( $<100$ years) of enhanced export production which are not discernible at the $10 \mathrm{~cm}$ resolution of our geochemical record.

It is interesting to note that the excess Ba concentrations calculated for $\mathrm{GCl}$ are mostly less than zero (Fig. 3e). This likely reflects (1) the diagenetic remobilisation of biogenic $\mathrm{Ba}$ under reducing conditions in the sediment column (thus rendering biogenic $\mathrm{Ba}$ unsuitable as a palaeoproductivity proxy), and (2) the presence of terrigenous components with a significantly lower $\mathrm{Ba} / \mathrm{Al}$ ratio than the crustal average of 0.0075 , such as quartz, in which $\mathrm{Al}$ is known to substitute for Si (Deer and others, 1977). The lowest values of excess Ba calculated for $\mathrm{GCl}$ roughly correspond to the upper three compositional episodes indicated by shaded bands in Figure 3, and may reflect increased diagenetic dissolution of biogenic barite under relatively reducing sedimentary conditions accompanying enhanced export production. In this respect, calculated excess Ba may provide some qualitative palaeoenvironmental information in anoxic continental-shelf sediments, with low concentrations indicating more reducing conditions within the sediment column.

The down-core chemical changes observed in $\mathrm{GCl}$ are generally absent from GC2, except at the base of the core which grades into sandier material. This core contains slightly lower concentrations of $\mathrm{Al}, \mathrm{Fe}$ and $\mathrm{Mn}$ (Fig. 3f), significantly higher ratios of $\mathrm{Mo} / \mathrm{Al}$ and $\mathrm{U} / \mathrm{Al}$ (Fig. $3 \mathrm{~g}$ ), slightly higher concentrations of opal (Fig. $3 \mathrm{~h}$ ) and significantly higher concentrations of TOC (Fig. 3i) than GCl. Downcore diatom assemblages are dominated by Fragilariopsis curta (personal communication from F. Taylor, 1997). These data suggest that the accumulation of biogenic and terrigenous material at the site of GC2 has been relatively consistent since the mid-Holocene, with a greater proportion of biogenic material and thus a more reducing sedimentary environment than at the GCl site. However, some downcore geochemical variations are observed for GC2: changes in $\mathrm{U} / \mathrm{Al}$ and particularly $\mathrm{Mo} / \mathrm{Al}$ (Fig. $3 \mathrm{~g}$ ), which suggest temporal variations in the sedimentary redox environment, and a general decrease in TOC with depth (Fig. 3i), which may reflect either a decreased accumulation of organic material in older sediments, or the diagenetic decomposition of organic carbon with increased depth in the sediment column (Berner, 1980). Another contrast with GCl is the calculated excess $\mathrm{Ba}$ concentrations in GC2, which are relatively uniform and all greater than zero (Fig. 3j). This may reflect a higher $\mathrm{Ba} / \mathrm{Al}$ ratio in the lithogenic material in $\mathrm{GC} 2$, or simply a greater deposition of biogenic barite such that accumulation of biogenic $\mathrm{Ba}$ has exceeded diagenetic loss from the sediment column.

\subsection{Sediment accumulation rates}

The down-core radiocarbon dates allow the calculation of average sediment accumulation rates between the dated sample depths for the two cores, which are shown in Figure $4 \mathrm{a}$ and $\mathrm{d}$ (for GCl and GC2, respectively). Compaction has been neglected in these calculations, and is assumed to be

\section{KROCK-GC1 outer shelf}

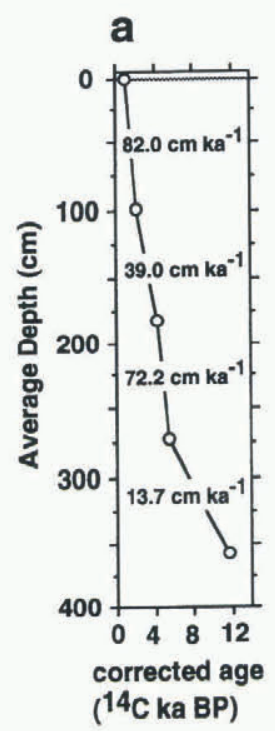

b

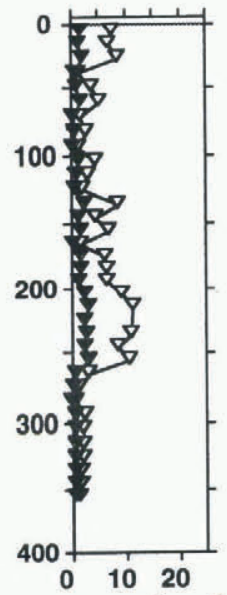

จopal $\left(\mathrm{g} \mathrm{cm}^{-2} \mathrm{ka}^{-1}\right)$
C

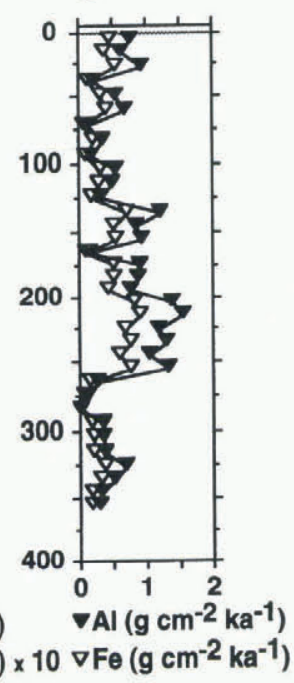

KROCK-GC2 inner shelf

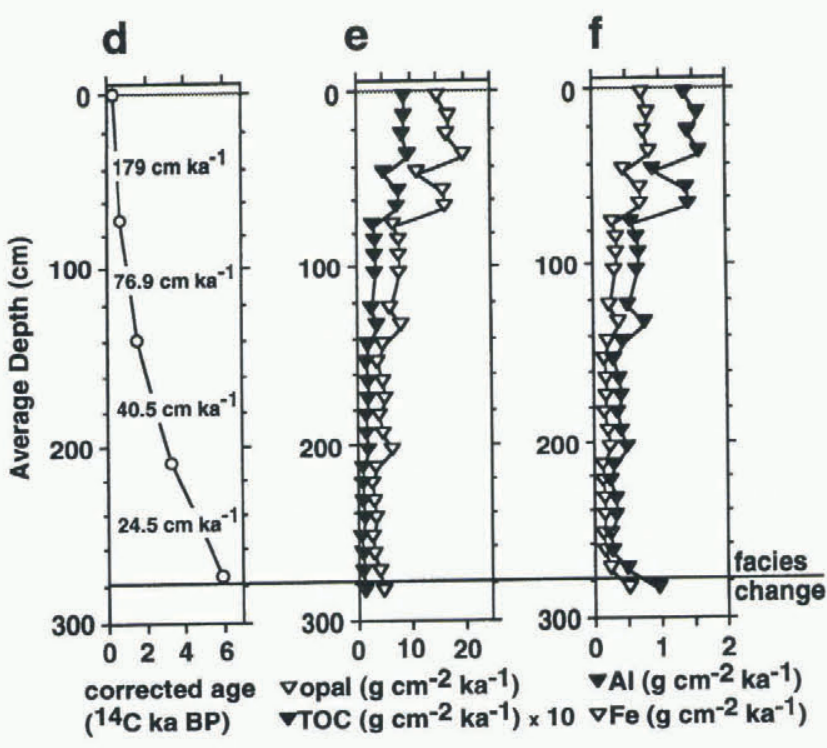

Fig. 4. Down-core corrected radiocarbon ages, average accumulation rates, and mass accumulation rates of opal, TOC, $\mathrm{Al}$ and $\mathrm{Fe}$ for cores KROCK-GC1 $(a-c)$ and KROCK-GC2 $(d-f)$.

small. If compaction is defined as water loss due to compression from overlying sediment (Berner, 1980), then this assumption is probably valid: large down-core variations in water content in GCl ( $\sim 40-90 \%$ water; data not shown) primarily reflect the observed layering within the core, and show no systematic decrease with depth, whereas for GC2 the decrease in down-core water content is less than $10 \%$ within the diatom ooze facies $(\sim 70-80 \%$ water; data not shown). Together with down-core bulk concentrations and measurements of dry bulk density, these calculated sediment accumulation rates may be used to estimate downcore material accumulation rates. These rates are presented for biogenic components (opal and TOC) in Figure 4b and e (for GCl and GC2, respectively), and for lithogenic components $(\mathrm{Al}$ and $\mathrm{Fe}$ ) in Figure $4 \mathrm{c}$ and $\mathrm{f}$ (for GCl and GC2, respectively).

The average accumulation rates calculated for $\mathrm{GCl}$ for the mid- to late Holocene range from 39 to $82 \mathrm{~cm} \mathrm{ka}^{-1}$ (Fig. 
4a). However, it should be noted that there are considerable uncertainties in these values arising from the observed layering in this core, which may represent short periods of rapid sediment accumulation that are unresolvable using radiocarbon dating. The average accumulation rate of $13.7 \mathrm{~cm} \mathrm{ka}^{-1}$ calculated for $\mathrm{GCl}$ in the early Holocene is likely too low, because it uses the $11660 \mathrm{ka}$ radiocarbon age obtained for darker material at the base of the core, which may include slowly accumulating and/or reworked pre-Holocene sediment. A more accurate estimate of sediment accumulation rate for this site during the early Holocene will require a radiocarbon date within the early Holocene $(<10 \mathrm{kaBP})$ section of the core (around 300-350 cm depth). The downcore material accumulation-rate estimates vary widely for $\mathrm{GCl}$, and these variations primarily reflect the large changes in down-core dry bulk density $\left(0.08-0.9 \mathrm{~g} \mathrm{~cm}^{-3}\right)$ and the low accumulation rate calculated for the lower section of the core. We believe that the accumulation-rate estimates shown in Figure $4 \mathrm{~b}$ and $\mathrm{c}$ are not representative of actual material accumulation rates for $\mathrm{GCl}$, because (1) the low values of dry bulk density reflect the fluffy layers which may have accumulated faster than the calculated average accumulation rates, and (2) the average accumulation rate calculated for the lower section of core is likely too low, as discussed above.

The average accumulation rates and material accumulation rates calculated for GC2 (Fig. 4d-f) are probably more reliable than those calculated for $\mathrm{GCl}$, because all radiocarbon dates are for material within the Holocene facies, and down-core bulk densities are relatively uniform $\left(0.27 \pm 0.05 \mathrm{~g} \mathrm{~cm}^{-3}\right)$. The calculated average accumulation rates for GC2 suggest a dramatic (>7-fold) increase in sediment accumulation rates from the middle to late Holocene, from $24.5 \mathrm{~cm} \mathrm{ka}^{-1}$ between 3330 and 5940 radiocarbon years BP to $179 \mathrm{~cm} \mathrm{ka}^{-1}$ between 300 and 690 radiocarbon years BP (Fig. 4d). Further, the estimated material accumulation rates suggest that there has been a similar 5-10-fold increase in the accumulation of biogenic (opal and TOC) and lithogenic $(\mathrm{Al}$ and $\mathrm{Fe})$ material at this site from the middle to late Holocene (Fig. $4 \mathrm{e}$ and $\mathrm{f}$ ).

Two general hypotheses may be offered to explain the apparently synchronous increases in the accumulation rate of biogenic and lithogenic material at the location of GC2 during the Holocene. The first is that the apparent increase in sediment accumulation rate is the result of changes in sediment transport processes or sediment focusing, such that sediments were transported into the inner Nielsen Basin from a progressively increasing "catchment" area during the Holocene, due to retreat of the ice sheet from the shelf or changes in shelf-water circulation. The second hypothesis is that the apparent increase in sediment accumulation rates reflects real increases in pelagic sedimentation in overlying waters, perhaps as a result of progressively decreasing permanent ice cover at this site during the Holocene, allowing comparable increases in biogenic export production and deposition of ice- and current-borne lithogenic material. Another possibility consistent with the second hypothesis is that primary production in these shelf waters is limited by the availability of dissolved iron in surface sea water, as has been suggested for offshore Antarctic waters (Martin and others, 1990) and shelf waters of the Ross Sea (Sedwick and DiTullio, 1997). In this case, the release of iron from lithogenic material entering surface waters might regulate algal export production.

\section{CONCLUSIONS AND FUTURE RESEARCH}

The results so far obtained for cores KROCK-GCl and KROCK-GC2 suggest quite different sedimentation histories for these two shelf locations during the Holocene. On the outer shelf, $\mathrm{GCl}$ apparently records three episodes of intense export production during the Holocene separated by periods of around 1500 years, and probably less pronounced "bloom episodes" which occurred over shorter periods. Long-term average sediment accumulation rates range from 39 to $82 \mathrm{~cm} \mathrm{ka}^{-1}$ during the middle and late Holocene. At present, our palaeoenvironmental interpretation of this core is limited by the $10 \mathrm{~cm}$ ( $>100$ year) resolution of the geochemical analyses and the much coarser resolution of the radiocarbon dates. Higher-resolution stratigraphic, geochemical and sedimentological analyses of this or similar cores, ideally at the scale of the visible bands within the core (i.e. on the order of $1-10 \mathrm{~cm}$ ), will allow us to better constrain the timing and duration of these bloom episodes and to better quantify material accumulation rates.

In contrast, our analysis of GC2 from the inner shelf suggests that there has been a roughly constant proportion of biogenic and lithogenic material accumulating at this location during the middle to late Holocene, with a somewhat higher proportion of biogenic material relative to the outer shelf. Notably, there is an apparent 7 -fold increase in average sediment accumulation rate (from 24.5 to $179 \mathrm{~cm} \mathrm{ka}^{-1}$ ) at this location between the middle and late Holocene, with roughly comparable increases in the accumulation of both biogenic and lithogenic material. This may represent changes in sediment transport processes; i.e. sediment focusing, or real increases in pelagic sedimentation at this location during the Holocene. In an effort to distinguish between these two possibilities, we are currently measuring ${ }^{230} \mathrm{Th}$ and ${ }^{231} \mathrm{~Pa}$ in GC2, which offers the possibility of quantifying sediment focusing (Frank and others, 1995) and evaluating changes in biogenic export production (Kumar and others, 1995).

\section{ACKNOWLEDGEMENTS}

The authors gratefully acknowledge P. O'Brien for collection of core material and initial encouragement, B. Connell for laboratory assistance, F. Taylor for diatom identification, and T. Trull, E. Domack, I. Goodwin and R. Anderson for insightful discussions. E. Domack and J. Anderson are thanked for reviewing the manuscript. Staff of the Isotope and Organic Geochemistry Laboratory of the Australian Geological Survey Organisation are thanked for performing the TOC determinations. Uranium-series measurements were accomplished with travel funding provided by the Australian Department of Industry, Science and Technology. The staff of the Australian Nuclear Science and Technology Organisation accelerator mass spectrometry facility are thanked for radiocarbon analyses, which were funded by grants from the Australian Institute of Nuclear Science and Engineering. The principal funding for this work was provided by the Antarctic CRC.

\section{REFERENCES}

Anderson, J. B. and B. F. Molnia. 1989. Glacial-marine sedimentation. Washington, DC, American Geophysical Union. (Short Course in Geology 9.)

Berner, R. A. 1980. Early diagenesis. Princeton, NJ, Princeton University Press. 
Calvert, S. E. and T. F. Pedersen. 1993. Geochemistry of recent oxic and anoxic marine sediments: implications for the geological record. Mar. Geol., 113(1-2), 67-88.

Charles, C. D., P. N. Froelich, M. A. Zibello, R. A. Mortlock and J. J. Morley. 1991. Biogenic opal in Southern Ocean sediments over the last 450,000 years: implications for surface water chemistry and circulation. Paleoceanography, 6(6), 697-728.

Comiso, J. C., C. R. McClain, C. W. Sullivan, J. P. Ryan and C. L. Leonard. 1993. Coastal zone color scanner pigment concentrations in the Southern Ocean and relationships to geophysical surface features. J. Geophys. Res., 98(C2), 2419-2451.

Crusius, J., S. Calvert, T. Pedersen and D. Sage. 1996. Rhenium and molybdenum enrichments in sediments as indicators of oxic, suboxic and sulfidic conditions of deposition. Earth Planet. Sci. Lett., 145(1-4), 65-78.

Deacon, G. 1984. The Antarctic circumpolar ocean. Cambridge, Cambridge University Press.

Deer, W. A., R. A. Howie and J. Zussman. 1977. An introduction to the rock-forming minerals. London, Longman.

Domack, E. W., T. A. Mashiotta, L. A. Burkley and S. E. Ishman. 1993.300year cyclicity in organic matter preservation in Antarctic fjord sediments. In Kennett, J. P. and D. A. Warnke, eds. The Antarctic paleoenvironment: a perspective on global change. Washington, DC, American Geophysical Union, 265-272. (Antarctic Research Series 60.)

Dymond, J., E. Suess and M. Lyle. 1992. Barium in deep-sea sediment: a geochemical proxy for paleoproductivity. Paleoceanography, 7(2), 163-181.

Frank, M. and 7 others. 1995. Sediment redistribution versus paleoproductivity change: Weddell Sea margin sediment stratigraphy and biogenic particle flux of the last 250,000 years deduced from ${ }^{230} \mathrm{Th}_{\mathrm{ex}},{ }^{10} \mathrm{Be}$ and biogenic barium profiles. Earth Planet. Sci. Lett., 136(3-4), 559-573.

Harris, P.T. and P. E. O'Brien. 1996. Geomorphology and sedimentology of the continental shelf adjacent to Mac. Robertson Land, East Antarctica: a scalped shelf. Geo-Mar. Lett., 16 (4), 287-296.

Harris, P.T., W. Howard, P. E. O'Brien, P. N. Sedwick and E. L. Sikes. In press. Quaternary Antarctic ice-sheet fluctuations and Southern Ocean palaeoceanography: natural variability studies at the Antarctic CRC. $\mathcal{F}$.
Australian Geol. Geophys.

Jordan, R.W., J. Priddle, C. J. Pudsey, P. F. Barker and M. J. Whitehouse. 1991. Unusual diatom layers in Upper Pleistocene sediments from the northern Weddell Sea. Deep-Sea Res., 38(7), 829-843.

Kumar, N. and 6 others. 1995. Increased biological productivity and export production in the glacial Southern Ocean. Nature, 378(6558), 675-680.

Leventer, A., E.W. Domack, S. E. Ishman, S. Brachfield, C. E. McClennen and P. Manley. 1996. Productivity cycles of 200-300 years in the Antarctic Peninsula region: understanding linkages among the sun, atmosphere, oceans, sea ice, and biota. Geol. Soc. Am. Bull., 108(12), 1626-1644.

Martin, J. H., S. E. Fitzwater and R. M. Gordon. 1990. Iron deficiency limits phytoplankton growth in Antarctic waters. Global Biogeochem. Cycles, 4(1), 5-12

Mortlock, R. A. and P. N. Froelich. 1989. A simple method for the rapid determination of biogenic opal in pelagic marine sediments. Deep-Sea Res., Ser. I, 36(9), 1415-1426.

Mortlock, R. A. and 6 others. 1991. Evidence for lower productivity in the Antarctic Ocean during the last glaciation. Nature, 351 (6323), 220-222.

Nunes Vaz, R. and G. Lennon. 1996. Physical oceanography of the Prydz Bay region of Antarctic waters. Deep-Sea Res., Ser. I, 43(5), 603-641.

Sedwick, P. N. and G. R. DíTullio. 1997. Regulation of algal blooms in Antarctic shelf waters by the release of iron from melting sea ice. Geophys. Res. Lett., 24 (20), 2515-2518.

Shimmield, G. B. 1984. The geochemistry and mineralogy of Pacific sediments, Baja California. (Ph.D. thesis, University of Edinburgh.)

Stuiver, M. and H.A. Polach. 1977. Discussion: reporting of ${ }^{14} \mathrm{C}$ data. Radiocarbon, 19 (3), 355-363.

Wedepohl, K. H. 1971. Environmental influences on the chemical composition of shales and clays. In Ahrens, L. H., ed. Physics and chemistry of the Earth. Oxford, Pergamon Press, 307-331.

Yang, Y. -L., H. Elderfield, T. F. Pedersen and M. Ivanovich. 1995. Geochemical record of the Panama Basin during the last glacial maximum carbon event shows that the glacial ocean was not suboxic. Geology, $23(12), 1115-1118$. 